\title{
Assessment of Composted Pelletized Poultry Litter as an Alternative to Chemical Fertilizers Based on the Environmental Impact of Their Production
}

\author{
Nikolett Éva Kiss *, János Tamás, Nikolett Szőllősi, Edit Gorliczay (D) and Attila Nagy (D) \\ Institute of Water and Environmental Management, University of Debrecen, 4032 Debrecen, Hungary; \\ tamas@agr.unideb.hu (J.T.); nszollosi@agr.unideb.hu (N.S.); edit.gorliczay@agr.unideb.hu (E.G.); \\ attilanagy@agr.unideb.hu (A.N.) \\ * Correspondence: kiss.nikoletteva@agr.unideb.hu
}

check for updates

Citation: Kiss, N.É.; Tamás, J.; Szőllősi, N.; Gorliczay, E.; Nagy, A. Assessment of Composted Pelletized Poultry Litter as an Alternative to Chemical Fertilizers Based on the Environmental Impact of Their Production. Agriculture 2021, 11, 1130. https://doi.org/10.3390/ agriculture 11111130

Academic Editor:

Vasileios Antoniadis

Received: 7 October 2021

Accepted: 8 November 2021

Published: 11 November 2021

Publisher's Note: MDPI stays neutral with regard to jurisdictional claims in published maps and institutional affiliations.

Copyright: (c) 2021 by the authors. Licensee MDPI, Basel, Switzerland. This article is an open access article distributed under the terms and conditions of the Creative Commons Attribution (CC BY) license (https:/ / creativecommons.org/licenses/by/ $4.0 /)$.
Abstract: Reducing the use of chemical fertilizers in agriculture is one of the EU Green Deal's priorities. Since poultry production is increasing worldwide, stabilized poultry litter such as composted pelletized poultry litter (CPPL) is an alternative fertilizer option. On the contrary, compared to chemical fertilizers, the environmental impacts of composted products have not been adequately studied, and no data are currently available for CPPL produced by a closed composting system, such as the Hosoya system. The aim of this research was to assess the role of CPPL as a potential alternative for chemical fertilizer by evaluating the environmental impact of CPPL production via the Hosoya system using common chemical fertilizers. Based on life cycle assessment (LCA), the environmental impact (11 impact categories) was determined for the production of $1 \mathrm{~kg}$ of fertilizer, as well as for the production of $1 \mathrm{~kg}$ of active substances (nitrogen $(\mathrm{N})$, phosphorus pentoxide $\left(\mathrm{P}_{2} \mathrm{O}_{5}\right)$, and potassium chloride $\left(\mathrm{K}_{2} \mathrm{O}\right)$ ) and the theoretical nutrient (NPK) supply of a 100 ha field with CPPL and several chemical fertilizer options. The production of CPPL per kilogram was smaller than that of the chemical fertilizers; however, the environmental impact of chemical fertilizer production per kilogram of active substance $\left(\mathrm{N}, \mathrm{P}_{2} \mathrm{O}_{5}\right.$, or $\left.\mathrm{K}_{2} \mathrm{O}\right)$ was lower for most impact categories, because the active substance was available at higher concentrations in said chemical fertilizers. In contrast, the NPK supply of a 100 ha field by CPPL was found to possess a smaller environmental impact compared to several combinations of chemical fertilizers. In conclusion, CPPL demonstrated its suitability as an alternative to chemical fertilizers.

Keywords: composted pelletized poultry litter; life cycle assessment; Hosoya composting; chemical fertilizers; EU Green Deal

\section{Introduction}

Chemical fertilizers provide nutrients to plants quickly and easily. Since relatively low amounts of chemical fertilizers with an increased active substance content are sufficient for productivity [1-3], the introduction of chemical fertilizers has decreased the usage of manure to a low level in intensive farming systems. Chemical fertilizers, on the other hand, can hasten the decomposition of soil organic matter, resulting in the degradation of soil structure. Excess fertilization also has the potential to pollute waterbodies by causing leaching and acidity [4-7]. Furthermore, several studies have shown that the production and use of chemical fertilizers produce high levels of $\mathrm{NO}_{x}$ and $\mathrm{N}_{2} \mathrm{O}$; moreover, the use of fertilizers also increases soil $\mathrm{CO}_{2}$ emissions [8-20]. With the overarching aim of making Europe climate neutral and sustainable by 2050, the EU introduced the European Green Deal. One of its key targets is to reduce the overall use of chemical fertilizers. The positive effects of the use of manure as a fertilizer for soil-plant systems, particularly on the environment, highlight the importance of organic matter-based fertilizer applications. The European Commission presented the "Farm to Fork Strategy" in the spring of 2020. This 
strategy is one of the major elements of the European Union's Green Deal aiming at the use of sustainable practices, including carbon management and storage in soil, improved nutrient management, and reductions in chemical fertilizer use in precision and organic farming, in order to improve water and soil quality and to reduce emissions [21].

Manure and other organic matters can be a viable alternative to chemical fertilizers since they play an important role in soil resource replenishment [22-27]. In recent years, one of the rapidly growing livestock sectors is broiler farming [28,29], which is expected to become even more important in the future [30-33] to meet the food demand of a growing population. Due to the growing broiler production, the issue of manure utilization is becoming more important not only from an environmental standpoint, but also from a circular economy aspect in accordance with the Green Deal.

In comparison to other organic matter-containing fertilizers, broiler manure includes a high percentage of readily available micro- and macro-elements for plants and enhances the soil physical characteristics, soil organic matter content, water-holding capacity, nutrient uptake, and, ultimately, plant productivity [34-39]. Raw poultry manure is highly recommended to be treated before use directly as a fertilizer due to its pathogen microorganism content. Composting produces a valuable and environmentally favorable end product [40]; however, the production process is not necessarily environmentally friendly, and therefore, the environmental impact of production must be evaluated. The degree of emissions is influenced by the quantity, quality, and composition, storage, and processing of manure, which includes several types of composting. According to Finstein [41], the main issue is with open composting technology, which pollutes the atmosphere by directly releasing gases, water vapor, and odors. $\mathrm{CO}_{2}$ loss is the most important and contributes greatly to the greenhouse effect, although there are studies that indicate that the effect of ammonia emissions contributes more to GHG emissions than $\mathrm{CO}_{2}$ [42]. When organic wastes and byproducts with a high nitrogen content are composted, one of the main compounds that causes pollution is ammonia. Ammonia emissions are an issue, not only because ammonia is hazardous to the environment [43-47], but because it also reduces the nitrogen content of the end product $[43,44]$. Therefore, potential emerging treatment options involve closed and intensive composting technologies, resulting in a lower ammonia loss and GHG emissions [48-50] compared to open composting systems. One such closed and intensive composting technology is the Hosoya system, which produces composted pelletized granules with heat treatment, thus eliminating toxic ammonia emissions, weed seeds, and pathogenic microorganisms [51,52]. Although the technological process of the Hosoya system is well studied [52], there are no studies related to the environmental impact of production based on life cycle assessment (LCA).

The aim of this research was to assess the role of composted and pelletized poultry litter (CPPL) as a potential alternative to chemical fertilizers by evaluating the environmental impacts of CPPL (53\% broiler manure and litter, 27\% manure layer and litter, 20\% chicken meal (meat and bone meal)) production via the Hosoya system using common chemical fertilizers (ammonium nitrate (AN), calcium ammonium nitrate (CAN), urea, triple superphosphate (TSP), monoammonium phosphate (MAP), and potassium chloride $(\mathrm{KCl})$ ). Since CPPL includes all macro-elements, based on a life cycle assessment, the environmental impact of CPPL and chemical fertilizer production was not only determined for $1 \mathrm{~kg}$ of the product and $1 \mathrm{~kg}$ of the active substance (NPK), but also for the nutrient supply of a field with CPPL and combinations of chemical fertilizers at the same NPK level.

\section{Materials and Methods}

Environmental impact analysis is a complex issue in agriculture. Therefore, the principles, the framework for life cycle assessment (LCA), and the four main phases of an LCA were based on the ISO14040:2006 standard [53] in this research (Figure 1). Though, the life cycle assessment standard is primarily developed for industry, with less frequent application in agricultural systems and byproducts. 


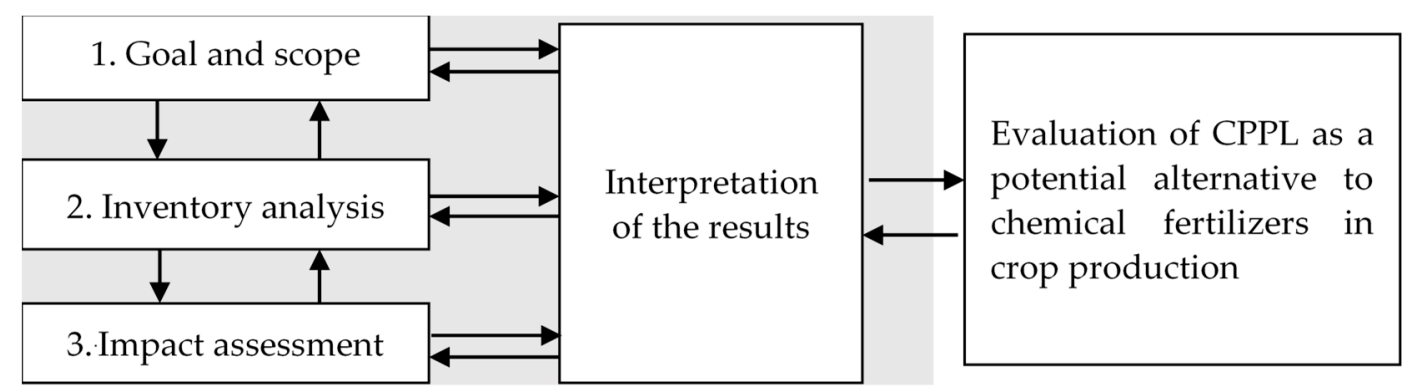

Figure 1. Steps of life cycle assessment (adopted from ISO14040:2006 [53]).

\subsection{Definition of the Goal and Scope of LCA}

The main objective of this analysis was to assess the role of CPPL as a potential alternative to chemical fertilizers by evaluating the environmental impact of CPPL production via the Hosoya system using common chemical fertilizers. Based on a life cycle assessment, the environmental impact (11 impact categories) was determined for:

- The production of $1 \mathrm{~kg}$ of fertilizers: $1 \mathrm{~kg}$ of composted pelletized poultry litter (CPPL) and $1 \mathrm{~kg}$ of the following chemical fertilizers: ammonium nitrate (AN), calcium ammonium nitrate (CAN), urea, triple superphosphate (TSP), monoammonium phosphate (MAP), and potassium chloride (KCl);

- The production of $1 \mathrm{~kg}$ of active substances separately for the $\mathrm{N}, \mathrm{P}_{2} \mathrm{O}_{5}$, and $\mathrm{K}_{2} \mathrm{O}$ content of fertilizers to provide comparable inputs to assess fertilizer production per unit of nutrient;

- The nutrient (NPK) supply of a 100 ha field with $1.5 \mathrm{Mg} /$ ha of CPPL (based on Szabó et al.'s [54] method), and with chemical fertilizer combinations with an equivalent NPK supply to analyze the environmental impacts of CPPL as a multi-element fertilizer.

\subsection{Life Cycle Inventory Analysis}

In the framework of inventory analysis, the input and output materials and energy flows were quantified for the Hosoya composting system using the data of a regionally important poultry producer company in Hungary. In the Hosoya composting plant, deep litter from broiler and layer poultry stock farms and filtered sewage sludge generated by slaughterhouses and hatcheries were collected and treated. The capacity of the plant is $10 \mathrm{mg} /$ day. Poultry houses were littered with heat-treated and grinded straw pellets. Due to the high absorbance capacity of these straw pellets, the deep litter manure also had a low moisture content. The parameters of the broiler and layer manure and litter are shown in Table 1.

Table 1. Parameters of broiler and layer manure and litter.

\begin{tabular}{ccc}
\hline Parameters & $\begin{array}{c}\text { Broiler Manure and } \\
\text { Litter } \mathbf{( 5 3 \% )}\end{array}$ & $\begin{array}{c}\text { Layer Manure and Litter } \\
\mathbf{( 2 7 \% )}\end{array}$ \\
\hline $\mathrm{N}$ content $(w / w \%)$ & $2.75 \pm 0.092$ & $2.14 \pm 0.151$ \\
$\mathrm{P}_{2} \mathrm{O}_{5}$ content $(\mathrm{mg} / \mathrm{kg})$ & $9344 \pm 63.692$ & $20,146 \pm 109.672$ \\
$\mathrm{~K}_{2} \mathrm{O}$ content $(\mathrm{mg} / \mathrm{kg})$ & $26,007 \pm 125.812$ & $27,306 \pm 244.178$ \\
Moisture content $(w / w \%)$ & $27.5 \pm 2.750$ & $25 \pm 1.944$ \\
Organic matter content $(w / w \%)$ & $64 \pm 1.541$ & $56 \pm 1.581$ \\
Calorific value $(\mathrm{J} / \mathrm{g})$ & $12,894 \pm 73.986$ & $10,532 \pm 51.088$ \\
$\mathrm{C} / \mathrm{N}$ ratio & $25 / 1$ & $25 / 1$ \\
\hline
\end{tabular}

The progress of Hosoya composting followed several steps:

Receipt of raw materials—storage, pre-treatment, and mixing: The raw materials were delivered by closed and covered manure transport vehicles. Dehydrated broiler and layer manure and litter were mixed (53\% broiler manure and litter, 27\% manure layer and litter, 
and $20 \%$ chicken meal). This mixture was stored until use in a closed manure storage building.

Storage of manure to oval tanks: Stored manure was transported to a loading hopper by front loaders. From the loading hopper, manure was transported to the entry points of the Japanese Hosoya-type manure oval tank system by belt feeders with rubber belts. The yearly capacity per a tank is $5000 \mathrm{mg}$ /year.

Moisture content optimization: For optimal composting, the moisture of the raw material must be adjusted to $40-45 w / w \%$ by adding sewage sludge (50 L/intake) and water (100 L/intake).

Composting: Controlled and monitored composting took place in the tanks. Proper ventilation was provided by a perforated pipe system at the bottom of said tanks, where the air was blown by a compressor. Depending on the technological need, it was possible to change the air temperature from 15 to $70^{\circ} \mathrm{C}$. The moisture content of the raw materials decreased to $22-28 w / w \%$ by the end of the procedure. Due to the intensive mixing and aeration, very intensive microbiological processes took place in the raw material during the decomposing process. The temperature varied between 60 and $70{ }^{\circ} \mathrm{C}$ for several days. At this temperature, weed seeds, which may have come from the litter, already lost their ability to germinate, and the number of colonies of several pathogenic bacteria decreased. The stirring machine with double rotors resulted in continuous mixing of the manure and litter in the tanks. The system completed a full run along the oval tank in approximately $4 \mathrm{~h}$, and the speed of the run was $0.8 \mathrm{~m} / \mathrm{min}$. On a daily basis, a maximum of six full runs were able to be completed. One complete run resulted in the displacement of $1.5 \mathrm{~m}$ of manure and litter along the tank or a maximum of $9.0 \mathrm{~m}$ after six runs completed in $24 \mathrm{~h}$. Otherwise, the raw materials would have cooled down too quickly and this would have hindered the process. The design of the tanks and the applied operational technology ensured a 14-day time period traveling time for fresh manure and litter to reach the exit point as compost (Figure 2). Continuous operation ensured that the same amount of manure and litter entered the tank as the amount of compost leaving it. In the technology, $5 \mathrm{~cm}$ thick compost remained at the bottom of the tank as a microbial starter. This layer was mixed with the added amount of fresh manure and litter.

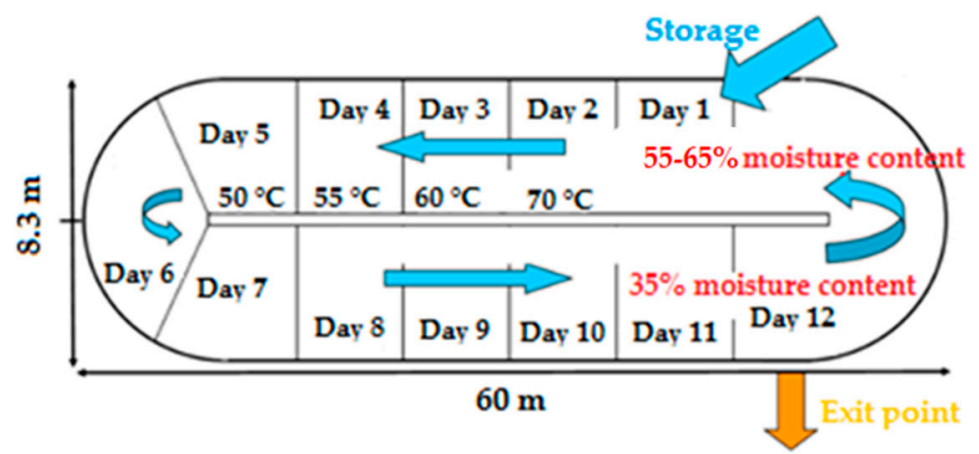

Figure 2. Poultry litter in the Hosoya oval composting tank from storage to the exit point.

Drying: Due to drying progress, it was further decreased from $22-28$ to $10-11 w / w \%$. Grinding: The dried, heat-treated, and sterile compost raw material was ground into a powder fraction, which became the raw material of the end products.

Pre-storage-nutrient supplementation: The ground compost was supplemented with meat and bone meal as additional nutrients with an $8.6 \% \mathrm{~N}$ content before granulation.

Granulation: Granulation occurred after nutrient supplement.

Cooling: The pellets could reach $80-95^{\circ} \mathrm{C}$ temperature after granulation, so it was required to cool down to $20-25^{\circ} \mathrm{C}$.

Aroma coating-packaging: The shaped and cooled pellets were coated with microcomponents, fragrances, and biostimulators. Finally, the CPPL was packaged. As a result of the above process, the content of the end product was as follows (Table 2). 
Table 2. Parameters of the end product.

\begin{tabular}{cccc}
\hline Parameters & \multicolumn{3}{c}{ Parameters } \\
\hline Moisture content $(w / w \%)$ & $12 \pm 1.189$ & B content $(\mathrm{mg} / \mathrm{kg})$ & $31.4 \pm 1.155$ \\
Organic matter content $(w / w \%)$ & $69 \pm 4.785$ & Fe content $(\mathrm{mg} / \mathrm{kg})$ & $545 \pm 13.976$ \\
Humus content $(w / w \%)$ & $51.84 \pm 1.378$ & Mn content $(\mathrm{mg} / \mathrm{kg})$ & $374 \pm 14.230$ \\
$\mathrm{~N}$ content $(w / w \%)$ & $5.5 \pm 0.606$ & Mo content $(\mathrm{mg} / \mathrm{kg})$ & $3.66 \pm 0.482$ \\
$\mathrm{P}_{2} \mathrm{O}_{5}$ content $(w / w \%)$ & $3 \pm 0.707$ & $\mathrm{Zn} \mathrm{content}(\mathrm{mg} / \mathrm{kg})$ & $367 \pm 39.438$ \\
$\mathrm{~K}_{2} \mathrm{O}$ content $(w / w \%)$ & $2.5 \pm 0.408$ & $\mathrm{Cu}$ content $(\mathrm{mg} / \mathrm{kg})$ & $53.3 \pm 1.811$ \\
$\mathrm{Ca}$ content $(w / w \%)$ & $6 \pm 0.770$ & $\mathrm{pH}$ & $7.2 \pm 0.532$ \\
$\mathrm{Mg}$ content $(w / w \%)$ & $0.5 \pm 0.264$ & Calorific value $(\mathrm{J} / \mathrm{g})$ & $15,092 \pm 151.391$ \\
$\mathrm{~S}$ content $(w / w \%)$ & $1 \pm 0.236$ & $\mathrm{C} / \mathrm{N} \mathrm{ratio}$ & $13 / 1$ \\
\hline
\end{tabular}

The input flows for the production of $1 \mathrm{~kg}$ of CPPL are listed in Table 3. The inputs represent the energy and material flows required for LCA.

Table 3. The flow inputs per kilogram of composted pelletized poultry litter end product.

\begin{tabular}{ccc}
\hline Flow of Inputs & Amount & Unit \\
\hline Poultry manure, fresh & 1.305 & $\mathrm{~kg}$ \\
Sludge, 4-6\%DM & 0.033 & $\mathrm{~kg}$ \\
Tap water & 0.067 & $\mathrm{~kg}$ \\
Diesel, burned in building machine & 0.087 & $\mathrm{MJ}$ \\
Electricity, medium voltage & 180.12 & $\mathrm{Wh}$ \\
Packaging, solid fertilizers or pesticides & 1.000 & $\mathrm{~kg}$ \\
\hline
\end{tabular}

A part of the data was provided by poultry manure treatment plant (manure, sludge, water, and fuel). However, data administration was based on our own calculations (electricity and emissions).

The inputs for the chemical fertilizers (AN, CAN, urea, TSP, MAP, and $\mathrm{KCl}$ ) were provided by the Agribalyse database [55]. All parameters (e.g., raw materials, such as ammonia for AN, CAN, urea, and MAP, dolomite and nitric acid for CAN, phosphate rock for TSP and MAP, phosphoric acid for TSP, and potash salt for $\mathrm{KCl}$; electricity; heat; steam in the chemical industry; tap water; and packaging) were included in the calculations, except for the transport processes to the application site, since transport is a highly changing variable in terms of distance, type of transport, and vehicle.

\subsection{The Life Cycle Impact Assessment}

In practice, LCA software is used to carry out life cycle impact assessments. The openLCA software was chosen for this life cycle assessment. Greendelta, a German software development company, created the software in 2006. The software is available for free download and use, and it allows for quick, accurate, and flexible modeling. The openLCA development team ensures that the software is updated on a regular basis.

There are several methods for assessing the impact of a project. The TRACI method, for example, is used in the United States. In Europe, the EcoIndicator, ReCiPe, ILCD, and CML methods are more widely used [56-59]. In this research, the CML $2001 \mathrm{impact}$ assessment method was used. This method was created at the University of Leiden in the Netherlands in 1992, and its name is derived from the acronym Centrum voor Milieukunde (CML) [57]. The most significant influence of CML's methodology is in the field of "impact assessment". The aim of the CML method is to quantitatively explore all direct material and energy exchange relationships between the natural environment and the product system. On the one hand, the method is based on the assumption that emissions with the same effect can be summarized across media and, on the other hand, on the impact-oriented classification of material and energy flows for impact assessment. The method is in line with international standardization efforts, as it covers target definition (goal and scope), life 
cycle inventory (inventory analysis), impact analysis (impact assessment), and evaluation (interpretation of the results) [57].

Within the openLCA software, the Agribalyse database was used because it provides a large number of LCIs of agricultural products [60-62].

The impact of emissions and consumption on the environment is illustrated with the following impact categories based on other authors [63,64]:

1. Abiotic depletion potential for elements (kg Sb-eq) (ADPe): The 'abiotic depletion potential for elements' refers to the extent of the use of non-renewable sources and minerals. It shows the per capita use of antimony $(\mathrm{Sb})$ and equivalent substances per year.

2. Abiotic depletion potential for fossil fuels (MJ) (ADPf): The 'abiotic depletion potential for fossil fuels' is shown in megajoules, instead of unit antimony equivalents ( $\mathrm{kg}$ $\mathrm{Sb}-\mathrm{eq})$ of the resource.

3. Acidification potential $\left(\mathrm{kg} \mathrm{SO}_{2}-\mathrm{eq}\right)(\mathrm{AP})$ : The acidification potential refers to compounds that cause acid rain $\left(\mathrm{SO}_{2}, \mathrm{NO}_{x}, \mathrm{NO}\right.$, and $\left.\mathrm{N}_{2} \mathrm{O}\right)$, usually denoted by the $\mathrm{SO}_{2}$ equivalent.

4. Eutrophication potential $\left(\mathrm{kg} \mathrm{PO}_{4}-\mathrm{eq}\right)(\mathrm{EP})$ : The eutrophication potential refers to the effects of over-fertilization or an excess supply of nutrients on terrestrial and aquatic environments, with a focus on the two most important nutrients, nitrogen $(\mathrm{N})$ and phosphorus (P). Eutrophication is indicated as the $\mathrm{PO}_{4}$ equivalent.

5. Global warming potential ( $\left.\mathrm{kg} \mathrm{CO}_{2}-\mathrm{eq}\right)(\mathrm{GWP})$ : The global warming potential is an index improved by the impact of the comparison of different gases on the atmosphere. A higher value of the GWP means a more negative impact on the environment. The basis of the GWP is usually a period of 100 years as the $\mathrm{CO}_{2}$ equivalent by its measurement.

6. Ozone layer depletion potential (kg CFC-11-eq) (ODP): To determine the ozone depleting potential, the CFC-11 equivalent is used to describe the emissions of all ozone-depleting substances.

7. Photochemical oxidation potential $\left(\mathrm{kg} \mathrm{C}_{2} \mathrm{H}_{4}\right.$-eq) (POP): The photochemical oxidation potential describes the ethylene equivalent emissions from photochemical oxidation due to a high NOx concentration.

8. Fresh water aquatic ecotoxicity potential (kg 1.4-DB-eq) (FAETP): This indicates the amount of contaminants in freshwater that have an impact on aquatic life pollution.

9. Human toxicity potential ( $\mathrm{kg}$ 1.4-DB-eq) (HTP): The maximum concentration of compounds that are hazardous to humans.

10. Marine aquatic ecotoxicity potential (kg 1.4-DB-eq) (MAETP): The marine aquatic ecotoxicity potential shows the effects of different chlorine compounds in the atmosphere on marine life and aquatic environments.

11. Terrestrial ecotoxicity potential (kg 1.4-DB-eq) (TETP): This shows the impact of various chlorine compounds on the environment and on humans.

\subsection{Methods for the Interpretation of LCA Results}

During the interpretation of the LCA results, comparative analyses were carried out to assess the environmental impacts of CPPL. At first, the environmental impact of $1 \mathrm{~kg}$ of CPPL was assessed compared to chemical fertilizers.

Then, the environmental impacts were determined separately for the production of $1 \mathrm{~kg}$ of active substances $\left(\mathrm{N}, \mathrm{P}_{2} \mathrm{O}_{5}\right.$, and $\left.\mathrm{K}_{2} \mathrm{O}\right)$ (Table 4). 
Table 4. Active substance content of fertilizers (N\%), $\left(\mathrm{P}_{2} \mathrm{O}_{5} \%\right)$, and $\left.\mathrm{K}_{2} \mathrm{O} \%\right)$ and the amount of fertilizer needed to apply $1 \mathrm{~kg}$ of the active substance.

\begin{tabular}{ccc}
\hline \multicolumn{2}{c}{ Active Substance Content (\%) } & \\
\hline Fertilizers & $\begin{array}{c}\text { Nitrogen content } \\
(\mathrm{N} \%)\end{array}$ & $\begin{array}{c}\text { Fertilizer (kg) for } \\
1 \mathrm{~kg} \text { of N }\end{array}$ \\
\hline Composted pelletized poultry litter (CPPL) & 5.5 & 18 \\
Ammonium nitrate (AN) & 33.5 & 2.99 \\
Calcium ammonium nitrate (CAN) & 27 & 3.7 \\
Urea & 46 & 2.17 \\
Monoammonium phosphate (MAP) & 12 & 8.33 \\
\hline & Phosphorus pentoxide & Fertilizer (kg) for \\
& content $\left(\mathrm{P}_{2} \mathrm{O}_{5} \%\right)$ & $1 \mathrm{~kg}$ of $\mathrm{P}_{2} \mathrm{O}_{5}$ \\
\hline Composted pelletized poultry litter (CPPL) & 3 & 33.33 \\
Triple superphosphate (TSP) & 46 & 2.17 \\
Monoammonium phosphate (MAP) & 52 & 1.92 \\
\hline & Potassium chloride & Fertilizer $(\mathrm{kg})$ for \\
& content $\left(\mathrm{K}_{2} \mathrm{O}_{\%}\right)$ & $1 \mathrm{~kg}$ of $\mathrm{K}_{2} \mathrm{O}$ \\
\hline Potassium chloride (KCl) & 2.5 & 40 \\
\hline
\end{tabular}

Finally, the environmental impact of producing the nutrient supply of a 100 ha field was assessed and evaluated. The production of $1.5 \mathrm{Mg} / \mathrm{ha}$ of CPPL was compared to the production of the CPPL equivalent macro-element content of N, P, and K fertilizers combined. The application of $1.5 \mathrm{Mg} / \mathrm{ha}$ (as an optimum based on Szabó et al. [54]) of CPPL was $82.5 \mathrm{~kg} / \mathrm{ha}$ of active $\mathrm{N}$ content, which is in line with Kátai's [65] recommendation of $80 \mathrm{~kg} / \mathrm{ha}$ as the minimum $\mathrm{N}$ requirement for soils with low and medium nitrogen supplies. First, the active substances of 1.5. Mg/ha of CPPL were calculated, and then the CPPL equivalent quantity of the chemical fertilizers was determined for 100 ha (Table 5).

Table 5. NPK treatments of 100 ha of arable land based on the parameters of composted poultry granules.

\begin{tabular}{ccc}
\hline & Quantity of Fertilizers (Mg/ha) & $\begin{array}{c}\text { Quantity of Fertilizers Per 100 ha } \\
\mathbf{( M g} / \mathbf{1 0 0} \text { ha) }\end{array}$ \\
\hline CPPL & 1.5 & 150 \\
AN & 0.246 & $24.6 / 21.5^{*}$ \\
CAN & 0.305 & $30.5 / 26.7^{*}$ \\
Urea & 0.18 & $18 / 15.7^{*}$ \\
TSP & 0.096 & 9.6 \\
MAP & 0.086 & 8.6 \\
KCl & 0.063 & 6.25 \\
\hline
\end{tabular}

${ }^{\text {}}$ Quantity of $\mathrm{N}$ fertilizers when the $\mathrm{P}$ fertilizer was MAP (considering the $\mathrm{N}$ content of MAP).

In order to supply the CPPL equivalent N, P, and K dosages on a 100 ha field, six combinations of chemical fertilizers were set, and the overall quantity of the combinations was determined (Table 6).

Table 6. Different treatments of the N, P, and K fertilizers.

\begin{tabular}{ccc}
\hline Name of Combination & NPK Combination & Mg/100 ha \\
\hline NPK1 & AN + TSP + KCl & 40.45 \\
NPK2 & AN + MAP + KCl & 36.35 \\
NPK3 & CAN + TSP + KCl & 46.15 \\
NPK4 & CAN + MAP + KCl & 41.51 \\
NPK5 & Urea + TSP + KCl & 33.85 \\
NPK6 & Urea + MAP + KCl & 30.59 \\
\hline
\end{tabular}


The environmental impact of CPPL and the six combinations of chemical fertilizers for fertilization of 100 ha was calculated using the quantity required for NPK fertilization of 100 ha and the previously calculated environmental impacts of $1 \mathrm{~kg}$ of CPPL and chemical fertilizers.

The CPPL and NPK combinations were identified to have low, medium, and high environmental impact. Three categories were defined based on dividing the difference between the maximum and minimum environmental impact category values into three equal intervals.

\section{Results}

\subsection{Environmental Impact by Producing $1 \mathrm{~kg}$ of CPPL and Chemical Fertilizers}

The environmental impact of CPPL production and different chemical fertilizers was evaluated per kilogram of the end product (Table 7). Out of the 11 impact categories, 9 cases (ADPe, ADPf, GWP, ODP, POP, FAETP, HTP, MAETP, and TETP) of CPPL production had the smallest environmental impact.

Table 7. Impact assessment of the production of $1 \mathrm{~kg}$ of CPPL and fertilizers.

\begin{tabular}{|c|c|c|c|c|c|c|c|}
\hline Impact Categories & CPPL & AN & CAN & Urea & TSP & MAP & $\mathrm{KCl}$ \\
\hline ADPe (kg Sb-eq) & $7.57 \times 10^{-8}$ & $6.47 \times 10^{-6}$ & $6.37 \times 10^{-6}$ & $7.43 \times 10^{-6}$ & $4.10 \times 10^{-7}$ & $6.70 \times 10^{-6}$ & $4.76 \times 10^{-6}$ \\
\hline $\operatorname{ADPf}(\mathrm{MJ})$ & 0.269 & 18.338 & 14.941 & 27.107 & 13.987 & 8.898 & 4.121 \\
\hline $\mathrm{AP}\left(\mathrm{kg} \mathrm{SO}{ }_{2}-\mathrm{eq}\right)$ & 0.024 & 0.006 & 0.005 & 0.005 & 0.010 & 0.003 & 0.002 \\
\hline $\mathrm{EP}(\mathrm{kg} \mathrm{PO}-\mathrm{eq})$ & 0.005 & 0.002 & 0.002 & 0.002 & 0.004 & 0.002 & 0.001 \\
\hline GWP $\left(\mathrm{kg} \mathrm{CO}_{2}-\mathrm{eq}\right)$ & 0.273 & 1.382 & 1.137 & 1.127 & 0.657 & 0.826 & 0.399 \\
\hline ODP (kg CFC-11-eq) & $3.48 \times 10^{-8}$ & $1.50 \times 10^{-7}$ & $1.23 \times 10^{-7}$ & $2.25 \times 10^{-7}$ & $1.01 \times 10^{-7}$ & $8.54 \times 10^{-8}$ & $3.73 \times 10^{-8}$ \\
\hline $\mathrm{POP}\left(\mathrm{kg} \mathrm{C} \mathrm{H}_{4}-\mathrm{eq}\right)$ & $2.87 \times 10^{-5}$ & $1.35 \times 10^{-4}$ & $1.17 \times 10^{-4}$ & $1.95 \times 10^{-4}$ & $4.29 \times 10^{-4}$ & $1.32 \times 10^{-4}$ & $7.97 \times 10^{-5}$ \\
\hline FAETP (kg 1.4-DB-eq) & 0.028 & 0.274 & 0.256 & 0.314 & 0.198 & 0.362 & 0.188 \\
\hline HTP (kg 1.4-DB-eq) & 0.032 & 0.449 & 0.429 & 0.534 & 0.172 & 0.502 & 0.334 \\
\hline MAETP (kg 1.4-DB-eq) & 47.419 & 663.080 & 616.340 & 790.531 & 523.135 & 833.587 & 504.535 \\
\hline TETP (kg 1.4-DB-eq) & $3.14 \times 10^{-4}$ & $1.51 \times 10^{-3}$ & $1.46 \times 10^{-3}$ & $1.82 \times 10^{-3}$ & $5.08 \times 10^{-3}$ & $6.48 \times 10^{-3}$ & $8.61 \times 10^{-4}$ \\
\hline
\end{tabular}

In the case of the abiotic depletion potential for elements, the best performing chemical fertilizer was TSP, but it was still five times higher than that of CPPL. For the abiotic depletion potential for fossil fuels, the environmental impact of producing $1 \mathrm{~kg}$ of CPPL was $93-99 \%$ smaller than the chemical fertilizer production.

Only the acidification and eutrophication potentials were the highest in the production of CPPL. The environmental impact of $1 \mathrm{~kg}$ of any chemical fertilizer production was $58-93 \%$ smaller in the case of the acidification potential and $24-88 \%$ smaller in the case of the eutrophication potential compared to CPPL production.

Among the chemical fertilizers, the GWP was the smallest in the production of $\mathrm{KCl}$ fertilizer. The highest emissions were found in the $\mathrm{N}$ fertilizers, especially in AN. The production of AN produced a five times higher GWP than CPPL.

The ozone depletion potential was the lowest in CPPL production and in $\mathrm{KCl}(7 \%$ higher than CPPL), while urea had the highest (85\% higher than CPPL).

In comparison, the environmental impact of CPPL production was $64-93 \%$ smaller in the case of the photochemical oxidation potential. The smallest emission value was calculated for $\mathrm{KCl}$ production, while the highest was for TSP amongst the chemical fertilizers.

In addition, of the chemical fertilizers, $\mathrm{KCl}$ fertilizer production generated the smallest emissions in the fresh water aquatic ecotoxicity potential (seven times higher than CPPL), the marine aquatic ecotoxicity potential (11 times higher than CPPL), and the terrestrial ecotoxicity potential (three times higher than CPPL). The highest emissions were produced by MAP production. The emission values of CPPL production were 92-95\% smaller than the MAP production in the case of these impact categories.

The human toxicity potential was the smallest for TSP, while urea had the highest. The emissions from CPPL production were $81-94 \%$ smaller than that of the chemical fertilizers. 
In summary, for the production of $1 \mathrm{~kg}$ of product, CPPL had the lowest environmental impact in 9 out of the 11 impact categories (ADPe, ADPf, GWP, ODP, POP, FAETP, HTP, MAETP, and TETP), while only 2 impact categories (AP and EP) had a higher environmental impact than the chemical fertilizer production.

\subsection{Environmental Impact by Producing of $1 \mathrm{~kg}$ of Active Substance}

The environmental impact was determined for $1 \mathrm{~kg}$ of active substance $\left(\mathrm{N}, \mathrm{P}_{2} \mathrm{O}_{5}\right.$, and $\mathrm{K}_{2} \mathrm{O}$ ) in addition to $1 \mathrm{~kg}$ of end product. Accordingly, the AN, CAN, and urea fertilizers were included for $1 \mathrm{~kg}$ of the $\mathrm{N}$ active substance, while the TSP and MAP fertilizers were included for $1 \mathrm{~kg}$ of the $\mathrm{P}_{2} \mathrm{O}_{5}$ active substance and the $\mathrm{KCl}$ fertilizer was included for $1 \mathrm{~kg}$ of the $\mathrm{K}_{2} \mathrm{O}$ active substance content of CPPL.

\subsubsection{Environmental Impact by Producing of $1 \mathrm{~kg}$ of the Nitrogen Active Substance}

Based on the emissions during production, a comparison of the CPPL product and the most major $\mathrm{N}$ fertilizers (AN, CAN, and urea) was carried out (Table 8). First, $1 \mathrm{~kg}$ of the $\mathrm{N}$ active substance was the functional unit. In 6 out of the 11 impact categories (AP, EP, GWP, ODP, POP, and TETP), the environmental impact was higher for CPPL production than for the $\mathrm{N}$ fertilizers.

Table 8. Impact assessment of the production of $1 \mathrm{~kg}$ of nitrogen content.

\begin{tabular}{|c|c|c|c|c|}
\hline Impact Categories & $\begin{array}{c}\text { CPPL } \\
(5.5 \% \mathrm{~N})\end{array}$ & $\begin{array}{c}\text { AN } \\
(33.5 \% \mathrm{~N})\end{array}$ & $\begin{array}{c}\text { CAN } \\
(27 \% \mathrm{~N})\end{array}$ & $\begin{array}{c}\text { Urea } \\
(46 \% \mathrm{~N})\end{array}$ \\
\hline ADPe (kg Sb-eq) & $1.38 \times 10^{-6}$ & $9.06 \times 10^{-6}$ & $2.36 \times 10^{-5}$ & $1.61 \times 10^{-5}$ \\
\hline $\operatorname{ADPf}(\mathrm{MJ})$ & 4.883 & 54.831 & 55.283 & 58.822 \\
\hline $\mathrm{AP}\left(\mathrm{kg} \mathrm{SO}{ }_{2}\right.$-eq $)$ & 0.439 & 0.019 & 0.019 & 0.010 \\
\hline $\mathrm{EP}(\mathrm{kg} \mathrm{PO}-\mathrm{eq})$ & 0.099 & 0.007 & 0.007 & 0.004 \\
\hline GWP (kg CO & 4.955 & 4.133 & 4.208 & 2.445 \\
\hline ODP (kg CFC-11-eq) & $6.33 \times 10^{-7}$ & $4.48 \times 10^{-7}$ & $4.57 \times 10^{-7}$ & $4.88 \times 10^{-7}$ \\
\hline $\mathrm{POP}\left(\mathrm{kg} \mathrm{C}_{2} \mathrm{H}_{4}\right.$-eq) & $5.23 \times 10^{-4}$ & $4.04 \times 10^{-4}$ & $4.32 \times 10^{-4}$ & $4.23 \times 10^{-4}$ \\
\hline FAETP (kg 1.4-DB-eq) & 0.518 & 0.819 & 0.947 & 0.681 \\
\hline HTP (kg 1.4-DB-eq) & 0.586 & 1.341 & 1.588 & 1.158 \\
\hline MAETP (kg 1.4-DB-eq) & 862.070 & 1982.609 & 2280.459 & 1715.452 \\
\hline TETP (kg 1.4-DB-eq) & 0.006 & 0.005 & 0.005 & 0.004 \\
\hline
\end{tabular}

In the instance of CAN, the highest abiotic depletion potential for elements was estimated (17 times higher than CPPL). The values of AN and urea were 6.5 and 11 times higher than those of CPPL.

Chemical fertilizers demonstrated abiotic depletion potential for fossil fuels values ranging from 54.8 (AN) to $58.8 \mathrm{MJ} / \mathrm{kg} \mathrm{N}$ (urea), while CPPL had a value of less than a 10th of these.

The acidification potential of the AN and CAN fertilizers was approximately equal, and the emissions from urea production were the smallest. The acidification potential of CPPL was 96-98\% higher than that of the $\mathrm{N}$ fertilizers.

CPPL's eutrophication potential was considerably higher than that of the nitrogen fertilizers. The estimated emission values of AN and CAN were equal, while urea had the smallest EP. The emissions show a 15-26 times difference between CPPL and the N fertilizers.

CPPL had the highest global warming potential (nearly $5 \mathrm{~kg} \mathrm{CO} / \mathrm{kg}$ of the $\mathrm{N}$ active substance). CAN and AN were close to $4 \mathrm{~kg}$ (on average, 16\% less emissions than CPPL). Urea had the lowest global warming potential value, which was nearly half that of CPPL.

In comparison to the nitrogen fertilizers, the ozone depletion, photochemical oxidation, and terrestrial toxicity potential values were all higher for CPPL. During the production of CPPL, the values of the above-mentioned impact categories were, on average, 30\% higher than in the case of AN, CAN, and urea production. 
During the production of CPPL, the values for the impact categories such as the freshwater aquatic ecotoxicity and marine aquatic ecotoxicity potentials, as well as the human toxicity potential, were the smallest. The emissions from the production of CAN were the highest of the impact categories: the freshwater aquatic ecotoxicity potential was $45 \%$ higher, while the human toxicity and marine aquatic ecotoxicity potentials were $62-63 \%$ higher than CPPL production. The emissions from the production of urea were the lowest of the three $\mathrm{N}$ fertilizers in these three impact categories. The freshwater aquatic ecotoxicity potential was $24 \%$ higher, while the human toxicity and marine aquatic ecotoxicity potentials were $49-50 \%$ higher than CPPL production.

Although only five impact categories (ADPe, ADPf, FAETP, HTP, and MAETP) had lower environmental impacts for CPPL, it should be taken into account that $\mathrm{N}$ fertilizers have a much higher $\mathrm{N}$ content and were much more concentrated.

\subsubsection{Environmental Impact by Producing of $1 \mathrm{~kg}$ of the Phosphate Active Substance}

The impact assessment of emissions was carried out during the production of phosphate fertilizers in the same way as it was for the $\mathrm{N}$ fertilizers. The functional unit used in the comparison of CPPL, TSP, and MAP was $1 \mathrm{~kg}$ of the $\mathrm{P}_{2} \mathrm{O}_{5}$ active substance (Table 9). The environmental impact of CPPL was highest for 6 out of the 11 impact categories (AP, EP, GWP, POP, FAETP, and HTP), while for ADPe and MAETP, CPPL was the second largest emitter.

Table 9. Impact assessment of the production of $1 \mathrm{~kg}$ of phosphate content.

\begin{tabular}{|c|c|c|c|}
\hline Impact Category & $\begin{array}{c}\text { CPPL } \\
\left(3 \% \mathrm{P}_{2} \mathrm{O}_{5}\right)\end{array}$ & $\begin{array}{c}\text { TSP } \\
\left(46 \% \mathrm{P}_{2} \mathrm{O}_{5}\right)\end{array}$ & $\begin{array}{c}\text { MAP } \\
\left(52 \% \mathrm{P}_{2} \mathrm{O}_{5}\right)\end{array}$ \\
\hline ADPe (kg Sb-eq) & $2.52 \times 10^{-6}$ & $8.90 \times 10^{-7}$ & $1.29 \times 10^{-5}$ \\
\hline $\operatorname{ADPf}(\mathrm{MJ})$ & 8.952 & 30.352 & 17.085 \\
\hline $\mathrm{AP}\left(\mathrm{kg} \mathrm{SO}{ }_{2}\right.$-eq $)$ & 0.804 & 0.022 & 0.007 \\
\hline $\mathrm{EP}(\mathrm{kg} \mathrm{PO}$-eq) & 0.181 & 0.009 & 0.003 \\
\hline GWP (kg CO $2-e q)$ & 9.084 & 1.426 & 1.587 \\
\hline ODP (kg CFC-11-eq) & $1.16 \times 10^{-6}$ & $2.20 \times 10^{-7}$ & $1.64 \times 10^{-7}$ \\
\hline POP $\left(\mathrm{kg} \mathrm{C}_{2} \mathrm{H}_{4}\right.$-eq) & 0.0010 & 0.0009 & 0.0003 \\
\hline FAETP (kg 1.4-DB-eq) & 0.949 & 0.429 & 0.694 \\
\hline HTP (kg 1.4-DB-eq) & 1.074 & 0.372 & 0.965 \\
\hline MAETP (kg 1.4-DB-eq) & 1580.462 & 1135.203 & 1600.487 \\
\hline TETP (kg 1.4-DB-eq) & 0.010 & 0.011 & 0.012 \\
\hline
\end{tabular}

The value of the abiotic depletion potential for elements was the highest in the production of MAP, being 5 times higher than CPPL and 14 times higher than TSP.

The abiotic depletion potential for fossil fuels was smallest for CPPL, being roughly half that of the value of MAP and one-third that of TSP.

In terms of the acidification potential, the emissions during the production of CPPL were, on average, $98 \%$ higher than the acidification potential of TSP and MAP.

The highest emissions based on the eutrophication potential were calculated for the production of CPPL. In comparison to the emissions of TSP and MAP production, $\mathrm{P}_{2} \mathrm{O}_{5}$ emissions per kilogram were 20 and 56 times higher, respectively.

In the case of the $\mathrm{P}$ fertilizers, the values of GWP were similar. The production of CPPL, on the other hand, emitted $83-84 \%$ greater $\mathrm{CO}_{2}$ than the $\mathrm{P}$ fertilizers.

Similarly to GWP, the ozone-depleting potential value for CPPL was the highest. CPPL produced emissions that were more than $80 \%$ higher than that of the P fertilizers.

The value of the photochemical oxidation potential was the lowest for MAP production. The emission rates for CPPL and TSP were nearly similar. These results were 73-74\% higher than the emissions produced by the MAP production process.

The freshwater aquatic ecotoxicity and human toxicity potential values were the highest in the production of CPPL. In comparison to CPPL, the freshwater aquatic ecotoxicity potential was $55 \%$ smaller during TSP production and $27 \%$ smaller during the production 
of MAP. In the case of the human toxicity potential, the TSP emissions were the lowest, whereas the MAP production emissions were only $10 \%$ lower than in the case of CPPL.

The greatest emissions in the production of MAP were observed in both the marine aquatic and terrestrial ecotoxicity potentials. In terms of the marine aquatic ecotoxicity potential, the MAP and CPPL emissions were nearly similar. TSP production had a $28 \%$ lower emission rate than CPPL production. For the terrestrial ecotoxicity potential, the emission value of CPPL production was the lowest. TSP production was $5 \%$ higher than the emissions of CPPL, while MAP production was 19\% higher.

It can be concluded that the emissions were clearly lower in just three cases-for ADPf, ODP, and TETP-during the production of CPPL. However, it must be taken into account that the phosphate content of CPPL (approximately 3\%) was lower than that of the fertilizers.

\subsubsection{Environmental Impact by Producing $1 \mathrm{~kg}$ of Potassium Content}

A comparison was made based on the emissions of CPPL and $\mathrm{KCl}$ fertilizer production. For this, $1 \mathrm{~kg}$ of the $\mathrm{K}_{2} \mathrm{O}$ active substance served as a functional unit (Table 10). Only ADPe had a lower environmental impact than CPPL (two and a half times lower), while $\mathrm{KCl}$ had a lower emission value for the other 10 impact categories.

Table 10. Impact assessment of the production of $1 \mathrm{~kg}$ of the potassium substance.

\begin{tabular}{ccc}
\hline Impact Category & $\begin{array}{c}\text { CPPL } \\
\left(\mathbf{2 . 5 \%} \mathbf{K}_{\mathbf{2}} \mathbf{O}\right)\end{array}$ & $\mathbf{K C l}$ \\
& $3.03 \times 10^{-6}$ & $7.90 \times 10^{-6}$ \\
ADPe (kg Sb-eq) & 10.744 & 6.840 \\
ADPf (MJ) & 0.965 & 0.003 \\
AP (kg SO $\mathbf{~}_{2}$-eq) & 0.218 & 0.001 \\
EP (kg PO -eq) & 10.901 & 0.663 \\
GWP (kg CO 2 -eq) & $1.39 \times 10^{-6}$ & $6.19 \times 10^{-8}$ \\
ODP (kg CFC-11-eq) & 0.0011 & 0.0001 \\
POP (kg C $\mathrm{H}_{4}$-eq) & 1.139 & 0.313 \\
FAETP (kg 1.4-DB-eq) & 1.289 & 0.554 \\
HTP (kg 1.4-DB-eq) & 1896.744 & 837.528 \\
MAETP (kg 1.4-DB-eq) & 0.013 & 0.001 \\
TETP (kg 1.4-DB-eq) & &
\end{tabular}

In terms of the abiotic depletion potential for fossil fuels, the production of $\mathrm{KCl}$ fertilizer emitted $36 \%$ less than CPPL.

The amount of acidification and eutrophication potentials during the production of CPPL was $99 \%$ higher than that of the production of $\mathrm{KCl}$.

In comparison to $\mathrm{KCl}$ fertilizer production, the global warming and ozone depleting potential values were $94 \%$ and $96 \%$ higher during the production of CPPL, respectively.

The emission rates were similar according to the results of the photochemical oxidation and terrestrial ecotoxicity potentials. In both impact categories, CPPL production had an $89 \%$ higher environmental impact.

In the case of the human toxicity and marine aquatic ecotoxicity potential impact categories, similar rates were obtained. The emission rate of CPPL production was $56-57 \%$ higher per $1 \mathrm{~kg}$ of the $\mathrm{K}_{2} \mathrm{O}$ active substance. The freshwater aquatic ecotoxicity potential values for the two products were different: the $\mathrm{KCl}$ fertilizer production emitted $73 \%$ lower emissions than CPPL production.

However, it should be noted that (as with the $\mathrm{N}$ and $\mathrm{P}_{2} \mathrm{O}_{5}$ substances) CPPL contained much less $\mathrm{K}_{2} \mathrm{O}\left(2.5 \% \mathrm{~K}_{2} \mathrm{O}\right)$ than the more concentrated $\mathrm{KCl}$ fertilizer $\left(60 \% \mathrm{~K}_{2} \mathrm{O}\right)$.

\subsection{Environmental Impact of a Medium-Sized Farm's Nutrient Replenishment}

The environmental impact of producing the nutrient supply of a 100 ha field was assessed and evaluated. The production of $1.5 \mathrm{Mg} / \mathrm{ha}$ of CPPL (150 Mg/100 ha) was 
compared to the production of the equivalent macro-element contents of the $\mathrm{N}, \mathrm{P}$, and $\mathrm{K}$ fertilizers combined (Table 11).

Table 11. Environmental emissions generated by the production of the applied CPPL and NPK treatments on 100 ha of arable land.

\begin{tabular}{|c|c|c|c|c|c|c|c|}
\hline Impact Category & CPPL & NPK1 & NPK2 & NPK3 & NPK4 & NPK5 & NPK6 \\
\hline ADPe (kg Sb-eq) & 0.011 & 0.193 & 0.227 & 0.228 & 0.257 & 0.167 & 0.205 \\
\hline $\operatorname{ADPf}(\mathrm{MJ})$ & 40,290 & 614,640 & 496,928 & 618,834 & 500,097 & 648,453 & 529,320 \\
\hline $\mathrm{AP}\left(\mathrm{kg} \mathrm{SO}_{2}-\mathrm{eq}\right)$ & 3620 & 262.9 & 173.3 & 265.3 & 175.3 & 196.0 & 115.6 \\
\hline $\mathrm{EP}\left(\mathrm{kg} \mathrm{PO} \mathrm{PO}_{4}-\mathrm{eq}\right)$ & 816.1 & 98.7 & 65.8 & 101.0 & 67.7 & 75.8 & 46.1 \\
\hline GWP $\left(\mathrm{kg} \mathrm{CO}_{2}-\mathrm{eq}\right)$ & 40,880 & 43,005 & 39,357 & 43,654 & 39,886 & 29,113 & 27,372 \\
\hline $\begin{array}{c}\text { ODP }(\mathrm{kg} \\
\text { CFC-11-eq) }\end{array}$ & 0.0052 & 0.0049 & 0.0042 & 0.0050 & 0.0043 & 0.0053 & 0.0045 \\
\hline POP $\left(\mathrm{kg} \mathrm{C}_{2} \mathrm{H}_{4}-\mathrm{eq}\right)$ & 4.31 & 8.02 & 4.54 & 8.25 & 4.74 & 8.18 & 4.71 \\
\hline $\begin{array}{l}\text { FAETP }(\mathrm{kg} \\
1.4-\mathrm{DB}-\mathrm{eq})\end{array}$ & 4,270 & 9862 & 10,192 & 10,923 & 11,109 & 8731 & 9241 \\
\hline HTP (kg 1.4-DB-eq) & 4833 & 14818 & 16,069 & 16,868 & 17,841 & 13,323 & 14,823 \\
\hline $\begin{array}{l}\text { MAETP (kg } \\
\text { 1.4-DB-eq) }\end{array}$ & 7112,789 & 24607,329 & 24610,646 & 27084,044 & 26749,074 & 22428,863 & 22797,379 \\
\hline $\begin{array}{l}\text { TETP (kg } \\
1.4-D B-e q)\end{array}$ & 47.06 & 92.30 & 93.98 & 99.47 & 100.18 & 87.60 & 90.08 \\
\hline
\end{tabular}

Green color = low environmental impact; yellow color = medium environmental impact; red color = high environmental impact.

With the production of $150 \mathrm{Mg}$ of CPPL, the abiotic depletion potential for elements and abiotic depletion potential for fossil fuels indicators were the smallest. Meanwhile, the production of various fertilizer combinations produced $93-95 \%$ higher emissions than CPPL on average.

However, compared to the chemical fertilizer treatments, the environmental impact of $150 \mathrm{Mg}$ of CPPL production was higher in terms of the acidification potential (94\% on average) and the eutrophication potential ( $90 \%$ on average). The possible reason for this, based on de Vries et al.'s [66] research, is that the main contributor to the high acidification potential of CPPL is ammonia, while the high eutrophication potential is due to nitrate emissions.

In comparison to the NPK1 and NPK3 combinations, CPPL produced a smaller global warming potential by $5.5 \%$ on average. CPPL's GWP values were similar to those of the NPK2 and NPK4 combinations. The GWP of those combinations where the $\mathrm{N}$ fertilizer was urea (NPK5 and NPK6) was 29-33\% lower than CPPL due to low environmental impact of urea production, because urea is the most concentrated nitrogen fertilizer $(46 \% \mathrm{~N})$ and smaller amounts of it cover the desired quantity.

There was no substantial difference between the NPK combinations and CPPL in terms of the ozone depletion potential (the values varied between 0.0042 and $0.0053 \mathrm{~kg}$ CFC-11-eq).

In those combinations where TSP was used for the P fertilizer (NPK1, NPK3, and NPK5), the photochemical oxidation potential value was, on average, $47 \%$ higher than the during the production of CPPL. Meanwhile, the value of this category was $7.5 \%$ higher when MAP was used.

The emissions were similar for the impact categories of the freshwater aquatic ecotoxicity potential, the marine aquatic ecotoxicity potential, the human toxicity potential, and the terrestrial ecotoxicity potential. When comparing the production of NPK to the production of CPPL, the freshwater ecotoxicity potential values were around $57 \%$ higher, on average, for the NPK fertilizer combinations. The emission value during the production of the chemical fertilizer combinations was, on average, $69-71 \%$ higher than the production of CPPL in terms of the human toxicity and marine aquatic ecotoxicity potentials. The terrestrial ecotoxicity potential was also higher in the production of chemical fertilizers, with an average of $50 \%$. 
Overall, Table 11 shows that the production of CPPL has a lower environmental impact than the production of equivalent macro-nutrient chemical fertilizers ( 7 out of the 11 impact categories were of "low environmental impact"). Out of all the chemical fertilizer combinations, NPK5 had the most favorable environmental impact. The NPK1, NPK2, NPK3, and NPK4 fertilizer combinations had the highest environmental impact, since AN or CAN fertilizers were the $\mathrm{N}$ source.

Additional calculations were carried out to determine the transportation-related environmental emissions associated with the CPPL and NPK fertilizer combinations mentioned above. To estimate distances of 10, 20, 50, and $100 \mathrm{~km}$, a vehicle with a carrying capacity of $15 \mathrm{t}$ was used. The results of CPPL and NPK fertilizer production were added to the emission data. As a result, transportation had no significant effect on the production-induced changes in emission rates.

\section{Discussion}

Although this study evaluated 11 environmental impact categories, the most extensively used and calculated impact category, the global warming potential, was used in order to understand the relevance of the calculated environmental impacts of CPPL and chemical fertilizers.

Since there is a lack of scientific knowledge in the field of environmental impact assessment that includes Hosoya technology's composted and pelletized poultry litter products, the CPPL product was compared with other organic matter treated with semiclosed and closed composting methods (Table 12).

Fresh laying hen manure and carcasses were composted by Zhu et al. [67]. When compared to CPPL based on Hosoya technology, the investigated composting technology emitted 3-6 times less $\mathrm{CO}_{2}$. Although, during the 11-week experiment, these compost piles were only remixed and reconstructed once compared to the continuously mixed Hosoya compost. Fresh air was introduced into each compost bin via an air distribution plate to provide ventilation.

Table 12. Global warming potential ( $\mathrm{kg} \mathrm{CO}_{2}$-eq) values based on a comparison between different composting technologies by scientific publications.

\begin{tabular}{cccc}
\hline & $\begin{array}{c}\mathbf{k g ~ C O} \text {-eq/ } \\
\text { kg of Product }\end{array}$ & Country/Region & Reference \\
\hline Hen carcasses and manure & $0.045-0.082$ & China & {$[67]$} \\
Sludge & $0.089-0.298$ & Europe & {$[68]$} \\
Chicken and cow manure & 0.147 & Egypt & {$[69]$} \\
Poultry manure & 0.27 & Europe & This study \\
Livestock waste & $0.475-2.307$ & Europe & {$[68]$} \\
\hline
\end{tabular}

The emissions were studied during the sewage sludge composting process in the frame of the scientific research program by ADAME [68]. According to their results, the observed emissions ranged between 0.089 and $0.298 \mathrm{~kg} \mathrm{CO}$-eq. In the framework of the ADAME program, the emissions from composting livestock waste were also evaluated. The measured emission rate in this investigation was five times higher than the emission value from the Hosoya composting technology.

Luske [69] examined the composting of chicken and cattle manure. The emissions generated from this composting plant were approximately $50 \%$ less $\left(0.147 \mathrm{~kg} \mathrm{CO}_{2}\right.$-eq $/ \mathrm{kg}$ of the product) compared to the emissions of Hosoya composting technology. The study also demonstrated that the composition and proportion of the input components have a major impact on emissions. Furthermore, composting technology (mixing, aeration, etc.) plays an important role in GWP production. The continuously mixed Hosoya composting technology investigated in this study was moderate compared to the results of other studies. 
The environmental effects of chemical fertilizer production have been widely studied. The $\mathrm{CO}_{2}$-equivalent gas emissions calculated for $1 \mathrm{~kg}$ of active substances were summarized to evaluate the results of the present study with other research works (Table 13).

The emissions from the production of AN varied between 3.5 and $7.2 \mathrm{~kg} \mathrm{CO} / \mathrm{eq} / \mathrm{kg}$ of $\mathrm{N}$ at the European level. The highest emission value was measured in China, where $10 \mathrm{~kg}$ of $\mathrm{CO}_{2}$-equivalent emissions per $1 \mathrm{~kg}$ of $\mathrm{N}$-substance were detected [70].

The emission factor of CAN production was also smaller in Europe. The rate of the $\mathrm{N}$ substance was $3.7 \mathrm{~kg} \mathrm{CO}_{2}$-eq [70], while it was $4.2 \mathrm{~kg} \mathrm{CO}_{2}$-eq for $1 \mathrm{~kg}$ of the $\mathrm{N}$ substance in this study. The emission factors in Russia, the USA, and China varied between 7.7 and $10.6 \mathrm{~kg} \mathrm{CO}$-eq.

In the case of urea production-related emissions, the European emission factors were as follows: 1.6 [71], 1.9 [69], and $3.5 \mathrm{~kg} \mathrm{CO}_{2}$-eq/ $\mathrm{kg}$ of $\mathrm{N}$ [72]. The value observed in this study was approximately the average of these three factors $\left(2.4 \mathrm{~kg} \mathrm{CO}_{2}\right.$-eq $/ \mathrm{kg}$ of $\left.\mathrm{N}\right)$. Higher emission values were calculated in China [70].

Among the $\mathrm{P}$ fertilizers, the global warming potential values generated by the production of TSP range from 0.4 to $1.6 \mathrm{~kg} \mathrm{CO}$-eq $/ \mathrm{kg}$ of $\mathrm{P}_{2} \mathrm{O}_{5}$ in Europe and throughout the world (1.42 $\mathrm{kg} \mathrm{CO}$-eq $/ \mathrm{kg}$ of $\mathrm{P}_{2} \mathrm{O}_{5}$ in this study) [70-72].

The emissions from the production of MAP are already much more variable. According to Brentrup et al. [70], the average emission factor is 1.4 in Europe, 1.7 in Russia and the USA, and $2.89 \mathrm{~kg} \mathrm{CO}-\mathrm{eq} / \mathrm{kg}$ of $\mathrm{P}_{2} \mathrm{O}_{5}$ in China. The factor calculated in present study is between the former two values $\left(1.6 \mathrm{~kg} \mathrm{CO}\right.$-eq $/ \mathrm{kg}$ of $\left.\mathrm{P}_{2} \mathrm{O}_{5}\right)$. Albaugh et al. [73] recorded a much higher factor in the USA, which was $6.4 \mathrm{~kg} \mathrm{CO}_{2}-\mathrm{eq} / \mathrm{kg}$ of $\mathrm{P}_{2} \mathrm{O}_{5}$. Based on Zhang et al.'s work [74], it varies between 7.8 and $8.9 \mathrm{~kg} \mathrm{CO}$-eq $/ \mathrm{kg}$ of $\mathrm{P}_{2} \mathrm{O}_{5}$ in China.

Table 13. Global warming potential $\left(\mathrm{kg} \mathrm{CO}_{2}\right.$-eq) values generated by the production of different chemical fertilizers.

\begin{tabular}{|c|c|c|c|}
\hline Chemical Fertilizers & $\begin{array}{c}\mathrm{kg} \mathrm{CO}-\mathrm{eq} / \\
\mathrm{kg} \text { of Active Substance }\end{array}$ & Country/Region & Reference \\
\hline $\begin{array}{l}\text { Ammonium nitrate } \\
(\mathrm{kg} \mathrm{CO} \text {-eq/ } \mathrm{kg} \text { of } \mathrm{N})\end{array}$ & $\begin{array}{c}4.1 \\
6.2 \\
7.2 \\
3.5 / 8 / 10.3\end{array}$ & $\begin{array}{c}\text { Europe } \\
\text { Europe } \\
\text { United Kingdom } \\
\text { Europe/Russia, USA/China }\end{array}$ & $\begin{array}{l}\text { This study } \\
{[71]} \\
{[72]} \\
{[70]}\end{array}$ \\
\hline $\begin{array}{l}\text { Calcium ammonium nitrate } \\
\left(\mathrm{kg} \mathrm{CO} \text { CO }_{2} / \mathrm{kg} \text { of } \mathrm{N}\right)\end{array}$ & $\begin{array}{c}3.7 / 7.7 / 8.7 / 10.6 \\
4.2\end{array}$ & $\begin{array}{c}\text { Europe/Russia/USA/China } \\
\text { Europe }\end{array}$ & $\begin{array}{c}\text { [70] } \\
\text { This study }\end{array}$ \\
\hline $\begin{array}{c}\text { Urea } \\
\left(\mathrm{kg} \mathrm{CO}_{2}-\mathrm{eq} / \mathrm{kg} \text { of } \mathrm{N}\right)\end{array}$ & $\begin{array}{c}1.6 \\
1.9 / 2.7 / 5.5 \\
2.4 \\
3.1 \\
3.5\end{array}$ & $\begin{array}{c}\text { Europe } \\
\text { Europe/Russia, USA/China } \\
\text { Europe } \\
\text { Southeastern USA } \\
\text { United Kingdom }\end{array}$ & $\begin{array}{c}\text { [71] } \\
\text { [70] } \\
\text { This study } \\
{[73]} \\
{[72]}\end{array}$ \\
\hline $\begin{array}{l}\text { Triple superphosphate } \\
\left(\mathrm{kg} \mathrm{CO}-\mathrm{eq} / \mathrm{kg} \text { of } \mathrm{P}_{2} \mathrm{O}_{5}\right)\end{array}$ & $\begin{array}{c}0.4-0.54 \\
1.2 \\
1.43 \\
1.6\end{array}$ & $\begin{array}{c}\text { Russia, USA, China } \\
\text { United Kingdom } \\
\text { Europe } \\
\text { Europe }\end{array}$ & $\begin{array}{c}{[70]} \\
{[72]} \\
\text { This study } \\
\text { [71] }\end{array}$ \\
\hline $\begin{array}{l}\text { Monoammonium phosphate } \\
\left(\mathrm{kg} \mathrm{CO}-\mathrm{eq} / \mathrm{kg} \text { of } \mathrm{P}_{2} \mathrm{O}_{5}\right)\end{array}$ & $\begin{array}{c}1.4 / 1.7 / 2.89 \\
1.6 \\
6.4 \\
7.8-8.9\end{array}$ & $\begin{array}{c}\text { Europe/Russia, USA/China } \\
\text { Europe } \\
\text { Southeastern USA } \\
\text { China }\end{array}$ & $\begin{array}{c}{[70]} \\
\text { This study } \\
{[73]} \\
{[74]}\end{array}$ \\
\hline $\begin{array}{c}\text { Potassium chloride } \\
\left(\mathrm{kg} \mathrm{CO}_{2}-\mathrm{eq} / \mathrm{kg} \text { of } \mathrm{K}_{2} \mathrm{O}\right)\end{array}$ & $\begin{array}{c}0.14-0.25 \\
0.23 \\
0.36 \\
0.55 \\
0.66\end{array}$ & $\begin{array}{c}\text { China } \\
\text { Europe } \\
\text { New Zealand } \\
\text { China } \\
\text { Europe }\end{array}$ & $\begin{array}{c}{[75]} \\
{[73]} \\
{[76]} \\
{[74]} \\
\text { this study }\end{array}$ \\
\hline
\end{tabular}


The global warming potential of the $\mathrm{N}$ and $\mathrm{P}$ fertilizer production in this study is similar to that of other studies in Europe. In general, it was also found that China has the highest values.

The emission factor $\left(0.66 \mathrm{~kg} \mathrm{CO}_{2}\right.$-eq $/ \mathrm{kg}$ of $\left.\mathrm{K}_{2} \mathrm{O}\right)$ in the present study for the production of the $\mathrm{KCl}$ fertilizer was close to the highest calculated value in China $(0.55 \mathrm{~kg} \mathrm{CO}$ equivalent) [74]. Based on other studies, the rate of this emission factor is between 0.14 and $0.36 \mathrm{~kg} \mathrm{CO}$-eq $/ \mathrm{kg}$ of $\mathrm{K}_{2} \mathrm{O}[73,75,76]$.

Since Hungary is in the region of Central Eastern Europe, the global warming potential of CPPL production for utilization of 100 ha was also assessed in Europe, including references for Russia. NPK combinations were calculated based on the relevant GWP references for Europe and Russia (listed in Table 13) using the method applied in this study to calculate NPK fertilizer combinations, which is described in Tables 5 and 6. The GWPs were calculated from the average of the European and Russian global warming potential values (Table 14).

Table 14. Global warming potential values from other scientific publications compared to this study.

\begin{tabular}{cccccccc}
\hline Impact Category & CPPL & NPK1 & NPK2 & NPK3 & NPK4 & NPK5 & NPK6 \\
\hline GWP $\left(\mathrm{kg} \mathrm{CO}_{2}\right.$-eq $)$ & 40,880 & 55,693 & 50,449 & 50,717 & 46,106 & 27,933 & 26,197 \\
\hline
\end{tabular}

The global warming potential for producing $150 \mathrm{Mg}$ of CPPL was $40,880 \mathrm{~kg} \mathrm{CO}_{2}$-eq. In comparison, the average $\mathrm{CO}_{2}$ equivalent emissions of NPK1 were $27 \%$ higher than those of CPPL. The GWP of NPK2 and NPK3 was 19\% higher than that of CPPL, while NPK4 had an $11 \%$ higher environmental impact. However, for the combinations of NPK5 and NPK6, where the $\mathrm{N}$ fertilizer was urea, the environmental impact was 32-36\% smaller.

\section{Conclusions}

As a final statement, considering the environmental impact by producing $1 \mathrm{~kg}$ of active substances, CPPL has a higher environmental impact compared to individual chemical fertilizers. On the contrary, considering that CPPL provides nutrients as a complex fertilizer, the CPPL equivalent combinations of chemical fertilizers have a higher impact in the case of the abiotic depletion potential for elements and abiotic depletion potential for fossil fuels, the photochemical oxidation potential, the human toxicity potential, the freshwater and marine aquatic ecotoxicity potentials, and the terrestrial ecotoxicity potential.

Considering the results, the nutrient (NPK) supply of a 100 ha field with $1.5 \mathrm{Mg} / \mathrm{ha}$ of CPPL, as well as combinations of chemical fertilizers with an equivalent NPK supply, CPPL is a potential alternative for the complex fertilization of arable lands. The only exemption is in those cases when urea was used in the NPK combinations (NPK5 and NPK6), due to its low environmental impact. Thus, CPPL can be used as a substitute for chemical fertilizer combinations where $\mathrm{N}$ replenishment is not provided by urea. Nevertheless, CPPL provides organic components; a high micro-element content; a number of other beneficial effects on soil fertility, structure, and organic matter content; and water management properties. Therefore, in further research, not only NPK but the micro-element content of CPPL too shall be included in further investigation to assess CPPL as a potential macroand micro-element complex fertilizer alternative for sets of chemical fertilizers.

Author Contributions: Conceptualization, A.N. and J.T.; methodology, N.É.K. and A.N.; software, N.É.K.; investigation, N.É.K., E.G. and N.S.; writing-original draft preparation, N.É.K. and A.N.; All authors have read and agreed to the published version of the manuscript.

Funding: The APC was funded by EFOP-3.6.3-VEKOP-16-2017-00008 project. The project is cofinanced by the European Union and the European Social Fund.

Institutional Review Board Statement: Not applicable.

Informed Consent Statement: Not applicable. 
Data Availability Statement: The datasets generated and/or analyzed during the current study are available from the corresponding author on reasonable request.

Acknowledgments: This research was supported by EU grant to Hungary GINOP 2.2.1.-15-201700043. The publication is supported by the EFOP-3.6.3-VEKOP-16-2017-00008 project. The project is co-financed by the European Union and the European Social Fund.

Conflicts of Interest: The authors declare that they have no conflict of interest.

\section{References}

1. Scholl, L.; Nieuwenhuis, R. Soil Fertility Management; Agromisa Foundation: Wageningen, The Netherlands, $2004 ;$ pp. 48-55.

2. Chen, J.-H.; Wu, J.-T.; Young, C. The Combined Use of Chemical and Organic Fertilizers and/or Biofertilizer for Crop Growth and Soil Fertility. Environ. Sci. 2007, 10, 1-12.

3. Han, S.H.; Young, J.; Hwang, J.; Kima, S.B.; Parka, B. The Effects of Organic Manure and Chemical Fertilizer on the Growth and Nutrient Concentrations of Yellow Poplar (Liriodendron tulipifera Lin.) in a Nursery System. For. Sci. Technol. 2016, 12, 137-143.

4. Alimi, T.; Ajewole, O.C.; Awosola, O.; Idowu, E.O. Organic and Inorganic Fertilizer for Vegetable Production under Tropical Conditions. J. Agric. Rural. Dev. 2007, 1, 120-136.

5. Savci, S. Investigation of Effect of Chemical Fertilizers on Environment. APCBEE Procedia 2012, 1, 287-292. [CrossRef]

6. Adediran, J.A.; Taiwa, L.B.; Akande, M.O.; Sobulo, R.A.; Idown, O.J. Application of Organic and Inorganic Fertilizer for Sustainable Maize and Cowpea Yield in Nigeria. J. Plant Nutr. 2004, 27, 1163-1181. [CrossRef]

7. Bíró, T.; Tamás, J.; Thyll, S. Risk assessment of nitrate pollution in lower watershed of the Berettyó River. In Soil Water Environment Relationships; Wageningen-Debrecen; Filep, G., Ed.; Wageningen University and Research: Wageningen, The Netherland; University of Debrecen: Debrcen, Hungary, 1998; pp. 239-247.

8. Dhadli, H.S.; Brar, B.S. Effect of long-term differential application of inorganic fertilizers and manure on soil $\mathrm{CO}_{2}$ emissions. Plant Soil Environ. 2016, 62, 195-201.

9. Adviento-Borbe, M.A.A.; Kaye, J.P.; Bruns, M.A.; McDaniel, M.D.; McCoy, M.; Harkcom, S. Soil Greenhouse Gas and Ammonia Emissions in Long-Term Maize-Based Cropping Systems. Soil Biol. Biochem. 2010, 74, 1623-1634. [CrossRef]

10. Mbonimpa, E.G.; Hong, C.O.; Owens, V.N.; Lehman, M.R.; Osborne, S.L.; Schumacher, T.E.; Clay, D.E.; Kumar, S. Nitrogen fertilizer and landscape position impacts on $\mathrm{CO}_{2}$ and $\mathrm{CH}_{4}$ fluxes from a landscape seeded to switchgrass. Glob. Chang. Biol.-Bioenergy 2014, 7, 836-849. [CrossRef]

11. Dhadli, H.S.; Brar, B.S.; Kingra, P.K. Temporal Variations in $\mathrm{N}_{2} \mathrm{O}$ Emissions in Maize and Wheat Crop Seasons: Impact of N-Fertilization, Crop Growth, and Weather Variables. J. Crop Improv. 2016, 30, 17-31. [CrossRef]

12. Peng, Q.; Dong, Y.S.; Qi, Y.C.; Xiao, S.S.; He, Y.T.; Ma, T. Effects of nitrogen fertilization on soil respiration in temper-ate grassland in Inner Mongolia, China. Environ. Earth Sci. 2011, 62, 1163-1171. [CrossRef]

13. Zhang, J.J.; Li, Y.F.; Jiang, P.K.; Zhou, G.M.; Shen, Z.M.; Liu, J.; Wang, Z.L. Effects of fertilization on soil CO $\mathrm{CO}_{2}$ flux in Castanea mollissima stand. J. Appl. Ecol. 2013, 24, 2431-2439.

14. Nyamadzawo, G.; Wuta, M.; Nyamangara, J.; Smith, J.L.; Rees, R.M. Nitrous oxide and methane emissions from cultivated seasonal wetland (dambo) soils with inorganic, organic and integrated nutrient management. Nutr. Cycl. Agroecosystems 2014, 100, 161-175. [CrossRef]

15. Khan, A.; Tan, D.K.Y.; Munsif, F.; Afridi, M.Z.; Shah, F.; Wei, F.; Fahad, S.; Zhou, R. Nitrogen nutrition in cotton and control strategies for greenhouse gas emissions: A review. Environ. Sci. Pollut. Res. 2017, 24, 23471-23487. [CrossRef] [PubMed]

16. Shao, R.; Deng, L.; Yang, Q.H.; Shangguan, Z.P. Nitrogen fertilization increase soil carbon dioxide efflux of winter wheat field: A case study in Northwest China. Soil Tillage Res. 2014, 143, 164-171. [CrossRef]

17. Zamanian, K.; Zarebanadkouki, M.; Kuzyakov, Y. Nitrogen fertilization raises $\mathrm{CO}_{2}$ efflux from inorganic carbon: A global assessment. Glob. Chang. Biol. 2018, 24, 2810-2817. [CrossRef]

18. Zhang, L.H.; Shao, H.B.; Wang, B.C.; Zhang, L.W.; Qin, X.C. Effects of nitrogen and phosphorus on the production of carbon dioxide and nitrous oxide in salt-affected soils under different vegetation communities. Atmos. Environ. 2019, 204, 78-88. [CrossRef]

19. Kong, D.L.; Li, S.Q.; Jin, Y.G.; Wu, S.; Chen, J.; Hu, T.; Wang, H.; Liu, S.; Zou, J. Linking methane emissions to methanogenic and methanotrophic communities under different fertilization strategies in rice paddies. Geoderma 2019, 347, 233-243. [CrossRef]

20. Lin, S.; Zhang, A.; Shen, G.; Shaaban, M.; Ju, W.; Cui, Y.; Duan, C.; Fang, L. Effects of inorganic and organic fertilizers on $\mathrm{CO}_{2}$ and $\mathrm{CH}_{4}$ fluxes from tea plantation soil. Sci. Anthr. 2021, 9, 090. [CrossRef]

21. COM. Communication from the Commission to the European Parliament, the European Council, the Council, the European Economic and Social Committee and the Committee of the Regions; The European Green Deal: Brussels, Belgium, 2019.

22. Moyo, S.; Swanepoel, F.J.C. Multifunctionality of livestock in developing communities. In The Role of Livestock in Developing Communities: Enhancing Multifunctionality, 1st ed.; Swanepoel, F.J.C., Stroebel, A., Moyo, S., Eds.; University of Free State (UFS) and the technical Centre for Agricultural and Rural Cooperation (CTA): Cape Town, South Africa; Wageningen, The Netherlands, 2010; pp. 1-11.

23. Mézes, L.; Nagy, A.; Gálya, B.; Tamás, J. Poultry feather wastes recycling possibility as soil nutrient. Eurasian J. Soil Sci. 2015, 4, 244-252. [CrossRef] 
24. Magnusson, U. Sustainable Global Livestock Development for Food Security and Nutrition Including Roles for Sweden; Ministry of Enterprise and Innovation: Stockholm, Sweden; Swedish FAO Committee: Stockholm, Sweden, 2016.

25. Gorliczay, E.; Boczonádi, I.; Kiss, N.É.; Tóth, F.A.; Pabar, S.A.; Biró, B.; Kovács, L.R.; Tamás, J. Microbiological Effectivity Evaluation of New Poultry Farming Organic Waste Recycling. Agriculture 2021, 11, 683. [CrossRef]

26. He, Z. Organic Animal Farming and Comparative Studies of Conventional and Organic Manures. In Animal Manure: Production, Characteristics, Environmental Concerns, and Management, 1st ed.; Waldrip, H.M., Pagliari, P.H., He, Z., Eds.; American Society of Agronomy: Madison, WI, USA, 2020; Volume 67, pp. 165-182.

27. He, Z.; Pagliari, P.H.; Waldrip, H.M. Applied and Environmental Chemistry of Animal Manure: A Review. Pedosphere 2016, 26, 779-816. [CrossRef]

28. Chia, S.Y.; Tanga, C.M.; van Loon, J.J.; Dicke, M. Insects for sustainable animal feed: Inclusive business models involving smallholder farmers. Curr. Opin. Environ. Sustain. 2019, 41, 23-30. [CrossRef]

29. Nalunga, A.; Komakech, A.J.; Jjagwe, J.; Magala, H.; Lederer. J. Growth characteristics and meat quality of broiler chickens fed earthworm meal from Eudrilus eugeniae as a protein source. Livest. Sci. 2021, 245, 104394. [CrossRef]

30. Enahoro, D.; Lannerstad, M.; Pfeifer, C.; Dominguez-Salas, P. Contributions of livestock-derived foods to nutrient supply under changing demand in low- and middle-income countries. Glob. Food Secur. 2018, 19, 1-10. [CrossRef]

31. Janković, L.J.; Petrujkić, B.; Aleksić, N.; Vučinić, M.; Teodorović, R.; Karabasil, N.; Relić, R.; Drašković, V.; Nenadović, K. Carcass characteristics and meat quality of broilers fed on earthworm (Lumbricus rubellus) meal. J. Hell. Vet. Med Soc. 2020, 71, 2031-2040. [CrossRef]

32. Kasule, L.; Katongole, C.; Nambi-Kasozi, J.; Lumu, R.; Bareeba, F.; Presto, M.; Ivarsson, E.; Lindberg, J.E. Low nutritive quality of own-mixed chicken rations in Kampala City, Uganda. Agron. Sustain. Dev. 2014, 34, 921-926. [CrossRef]

33. Van Harn, J.; Dijkslag, M.A.; Van Krimpen, M.M. Effect of low protein diets supplemented with free amino acids on growth performance, slaughter yield, litter quality, and footpad lesions of male broilers. Poult. Sci. 2019, 98, 4868-4877. [CrossRef] [PubMed]

34. Mohamed, A.M.; Sekar, S.; Muthukrishnan, P. Prospects and potential of poultry manure. Asian J. Plant Sci. 2010, 9, 172-182. [CrossRef]

35. Garg, S.; Bahla, G.S. Phosphorus availability to maize as influenced by organic manures and fertilizer P associated phosphatase activity in soils. Bioresour. Technol. 2008, 99, 5773-5777. [CrossRef]

36. Bauer, A.; Black, A.L. Organic carbon effects on available water capacity of three soil textural groups. Soil Sci. Soc. Am. J. 1992, 56, 248-254. [CrossRef]

37. Tisdall, J.M.; Oades, J.M. Organic matter and water-stable aggregates in soils. J. Soil Sci. 1993, 33, 141-163. [CrossRef]

38. Mbah, C.N.; Nnej, I.R. Effect of different crop residue management technique on selected soil properties and grain production of maize. Afr. J. Agric. Res. 2011, 6, 4149-4152.

39. Ojeniyi, S.O.; Amusan, O.A.; Adekiya, A.O. Effect of poultry manure on soil physical properties, nutrient uptake and yield of cocoyam (Xanthosoma saggitifolium) in southwest Nigeria. Am.-Eurasian J. Agric. Environ. Sci. 2013, 13, 121-125.

40. Modderman, C. Composting with or without Additives. In Animal Manure: Production, Characteristics, Environmental Concerns, and Management; Waldrip, H.M., Pagliari, P.H., He, Z., Eds.; American Society of Agronomy: Madison, WI, USA, 2020; Volume 67, pp. 245-254.

41. Finstein, M.S. Composting in the context of municipal solid waste management. In Environmental Microbiology; Mitchell, R., Ed.; Wiley-Liss, Inc.: New York, NY, USA, 1992; pp. 355-374.

42. Kirchmann, H.; Witter, E. Ammonia volatilization during aerobic and anaerobic manure decomposition. Plant Soil 1989, 115, 35-41. [CrossRef]

43. Martins, O.; Dewes, T. Loss of nitrogenous compounds during composting of animal wastes. Bioresour. Technol. 1992, 42, 103-111. [CrossRef]

44. Beck-Friis, B.; Smårs, S.; Jönsson, H.; Kirchmann, H. Gaseous emissions of carbon dioxide, ammonia, and nitrous oxide from organic household waste in a compost reactor under different temperature regimes. J. Agric. Eng. Res. 2001, 78, 423-430. [CrossRef]

45. Zhang, W.; Lau, A. Reducing ammonia emission from poultry manure composting via struvite formation. J. Chem. Technol. Biotechnol. 2007, 82, 598-602. [CrossRef]

46. Eghball, B.; Power, J.F.; Gilley, J.E.; Doran, J.W. Nutrient, carbon, and mass loss during composting of beef cattle feedlot manure. J. Environ. Qual. 1997, 26, 189-193. [CrossRef]

47. Eklind, Y.; Kirchmann, H. Composting and storage of organic household waste with different litter amendments. II: Nitrogen turnover and losses. Bioresour. Technol. 2000, 74, 125-133. [CrossRef]

48. García, A.; Fox, J.G.; Besser, T.E. Zoonotic enterohemorrhagic Escherichia coli: A One Health perspective. ILAR J. 2010, 51, 221-232. [CrossRef] [PubMed]

49. García-Heredia, A.; Pohane, A.A.; Melzer, E.S.; Carr, C.R.; Fiolek, T.J.; Rundell, S.R.; Lim, H.C.; Wagner, J.C.; Morita, Y.S.; Swarts, B.M.; et al. Peptidoglycan precursor synthesis along the sidewall of pole-growing mycobacteria. eLife 2018, 7, 37243. [CrossRef]

50. Ke, W.; Chao, H.; Shijie, Y.; Weijie, L.; Wei, W.; Ruijun, Z.; Huanhuan, Q.; Nanqi, R. Transformation of organic matters in animal wastes during composting. J. Hazard. Mater. 2015, 300, 745-753. 
51. Georgakakis, D.; Krintas, T. Optimal use of the Hosoya system composting poultry manure. Bioresour. Technol. 2000, 72, 227-233. [CrossRef]

52. Hosoya \& Co. Hosoya Manure Fermentation, System; Hoyosa \& Co.: Kanagawa, Japan, 1996.

53. ISO. ISO14040 Environmental Management_Life Cycle Assessment_Principles and Framework; International Organization for Standardization (ISO); Standards Policy and Strategy Committee: London, UK, 2006.

54. Szabó, A.; Tamás, J.; Nagy, A. Spectral evaluation of the effect of poultry manure pellets on pigment content of maize (Zea mays L.) and wheat (Triticum aestivum L.) seedlings. Nat. Resour. Sustain. Dev. 2019, 9, 70-79. [CrossRef]

55. OpenLCA Nexus, Databases, Agribalyse. Available online: https://nexus.openlca.org/database/Agribalyse (accessed on 23 April 2021).

56. Guinee, J.B.; Gorree, M.; Heijungs, R.; Huppes, G.; Kleijn, R.; de Koning, A.; van Oers, L.; Sleeswijk, A.W.; Suh, S.; Udo de Haes, H.A.; et al. Handbook on Life Cycle Assessment-Operational Guide to the ISO Standards; Kluwer Academic Publisher: New York, NY, USA; Boston, MA, USA; Dordrecht, The Netherlands; London, UK; Moscow, Russia, 2002.

57. Gabathuler, H. The CML Story: How Environmental Sciences Entered the Debate on LCA. Int. J. Life Cycle Assess. 2006, 11, 127-132. [CrossRef]

58. Kabakian, V.; McManus, M.; Harajli, H. Attributional life cycle assessment of mounted $1.8 \mathrm{kWp}$ monocrystalline photovoltaic system with batteries and comparison with fossil energy production system. Appl. Energy 2015, 154, 428-437. [CrossRef]

59. Lamnatou, C.; Chemisana, D. Evaluation of photovoltaic-green and other roofing systems by means of ReCiPe and multiple life cycle-based environmental indicators. Build. Environ. 2015, 93, 376-384. [CrossRef]

60. Colomb, V.; Amar, S.A.; Mens, C.B.; Gac, A.; Gaillard, G.; Koch, P.; Mousset, J.; Salou, T.; Tailleur, A.; van der Werf, H.M.G. AGRIBALYSE $^{\circledR}$, the French LCI Database for agricultural products: High quality data for producers and environmental labelling. Oilseeds Fats Crop. Lipids 2015, 22, D104. [CrossRef]

61. Koch, P.; Salou, T. AGRIBALYSE ${ }^{\circledR}:$ Methodology, Agricultural Stage-Version 3.0; Ed ADAME: Angers, France, 2020.

62. Asselin-Balençon, A.; Broekema, R.; Teulon, H.; Gastaldi, G.; Houssier, J.; Moutia, A.; Rousseau, V.; Wermeille, A.; Colomb, V. AGRIBALYSE v3.0: The French Agricultural and Food LCI Database. Methodology for the Food Products; ADEME: Angers, France, 2020.

63. Gaidajis, G.; Kakanis, I. Life Cycle Assessment of Nitrate and Compound Fertilizers Production-A Case Study. Sustainability 2021, 13, 148. [CrossRef]

64. Baldini, C.; Bava, L.; Zucali, M.; Guarino, M. Milk production Life Cycle Assessment: A comparison between estimated and measured emission inventory for manure handling. Sci. Total Environ. 2018, 625, 209-219. [CrossRef]

65. Kátai, J. Determination of nitrogen doses (In Hungarian: Nitrogén dózisok megállapítása). In Soil ecology (In Hungarian: Talajökológia), 1st ed.; Kátai, J., Ed.; University Press, University of Debrecen: Debrecen, Hungary; University of West Hungary: Sopron, Hungary; University of Pannonia: Veszprém, Hungary, 2011; pp. 59-61.

66. de Vries, J.W.; Corré, W.J.; van Dooren, H.J.C. Environmental Assessment of Untreated Manure Use, Manure Digestion and Co-Digestion with Silage Maize; Report 372; Wageningen UR Livestock Research, part of Stichting Dienst Landbouwkundig Onderzoek (DLO Foundation): Wageningen, The Netherlands, 2010.

67. Zhu, Z.; Dong, H.; Xi, J.; Xin, H. Ammonia and greenhouse gas emissions from co-composting of dead hens with manure as affected by forced aeration rate. Trans. ASABE Am. Soc. Agric. Biol. Eng. 2014, 57, 211-217.

68. ADEME. Programme de Recherche de l'ADEME sur les Émissions Atmosphériques du Compostage. Connaissances Acquises et Synthèse Bibliographique; Isabelle, D., Ed.; Agence de l'Environnement et de la Maîtrise de l'Energie, Waste Prevention and Management Department-Substainable Consumption and Waste Division: Angers, France, 2012.

69. Luske, B. Reduced GHG Emissions due to Compost Production and Compost Use in Egypt. Comparing Two Scenarios; 2010-016 LbD.; Louis Bolk Instituut: Bunnik, The Netherlands, 2010.

70. Brentrup, F.; Hoxha, A.; Christensen, B. Carbon footprint analysis of mineral fertilizer production in Europe and other world regions. In Proceedings of the 10th International Conference on Life Cycle Assessment of Food (LCA Food 2016), Dublin, Ireland, 19-21 October 2016.

71. Skowrońska, M.; Filipek, T. Life cycle assessment of fertilizers: A review. Int. Agrophysics 2014, 28, 101-110. [CrossRef]

72. Williams, A.G.; Audsley, E.; Sandars, D.L. Environmental burdens of producing bread wheat, oilseed rape and potatoes in England and Wales using simulation and system modelling. Int. J. Life Cycle Assess. 2010, 15, 855-868. [CrossRef]

73. Albaugh, T.J.; Vance, E.D.; Gaudreault, C.; Fox, T.R.; Allen, H.L.; Stape, J.L.; Rubilar, R.A. Carbon Emissions and Sequestration from Fertilization of Pine in the Southeastern United States. For. Sci. 2012, 58, 419-429. [CrossRef]

74. Zhang, W.-F.; Dou, Z.-X.; He, P.; Ju, X.-T.; Powlson, D.S.; Chadwick, D.R.; Norse, D.; Lu, Y.-L.; Zhang, Y.; Wu, L. New technologies reduce greenhouse gas emissions from nitrogenous fertilizer in China. Proc. Natl. Acad. Sci. USA 2013, 110, 8375-8380. [CrossRef]

75. Chen, W.; Geng, Y.; Hong, J.; Yang, D.; Ma, X. Life cycle assessment of potash fertilizer production in China. Resour. Conserv. Recycl. 2018, 138, 238-245. [CrossRef]

76. Ledgard, S.F.; Lieffering, M.; Zonderland-Thomassen, M.A.; Boyes, M. Life cycle assessmenta-A tool for evaluating resource and environmental efficiency of agricultural products and systems from pasture to plate. Proc. New Zealand Soc. Anim. Prod. 2011, $71,139-148$. 